\title{
Article \\ Geochemical Characteristics and Ecological Risk Assessment of Heavy Metals in Surface Soil of Gaomi City
}

\author{
Zongjun Gao ${ }^{1}$, Hongzhi Dong ${ }^{1}$, Songtao Wang ${ }^{2,3}$, Yuqi Zhang ${ }^{1, *}$, Hairui Zhang ${ }^{2,3}$, Bing Jiang ${ }^{2,3}$ and Yang Liu ${ }^{2,3}$ \\ 1 College of Earth Science and Engineering, Shandong University of Science and Technology, \\ Qingdao 266590, China; zongjungao1964@163.com (Z.G.); dhz@sdust.edu.cn (H.D.) \\ 2 The Fourth Geological Brigade of Shandong Provincial Bureau of Geology and Mineral Resources, \\ Weifang 261021, China; wangsongtao@sddksy.com (S.W.); zhanghairui@sddksy.com (H.Z.); \\ jiangbing@sddksy.com (B.J.); liuyang@sddksy.com (Y.L.) \\ 3 Key Laboratory of Coastal Zone Geological Environment Protection of Shandong Geology and Mineral \\ Exploration and Development Bureau, Weifang 261021, China \\ * Correspondence: zyqsdust@163.com; Tel.: +86-188-6397-8186
}

Citation: Gao, Z.; Dong, H.; Wang, S.; Zhang, Y.; Zhang, H.; Jiang, B.; Liu, Y. Geochemical Characteristics and Ecological Risk Assessment of Heavy Metals in Surface Soil of Gaomi City. Int. J. Environ. Res. Public Health 2021, 18, 8329. https://doi.org/10.3390/ ijerph18168329

Academic Editor: Paul B. Tchounwou

Received: 1 July 2021

Accepted: 30 July 2021

Published: 6 August 2021

Publisher's Note: MDPI stays neutral with regard to jurisdictional claims in published maps and institutional affiliations.

Copyright: (c) 2021 by the authors. Licensee MDPI, Basel, Switzerland. This article is an open access article distributed under the terms and conditions of the Creative Commons Attribution (CC BY) license (https:// creativecommons.org/licenses/by/ $4.0 /)$.

\begin{abstract}
Gaomi City, the hinterland of Jiaolai Plain in Shandong Peninsula, was selected as the research object. A total of 8197 surface soil samples were collected to determine the contents of eight soil heavy metals (HMs)including Copper $(\mathrm{Cu})$, Lead $(\mathrm{Pb})$, Zinc $(\mathrm{Zn})$, Nickel (Ni), Chromium $(\mathrm{Cr})$, Cadmium $(\mathrm{Cd})$, Arsenic (As), and Mercury $(\mathrm{Hg})$. Statistical methods were used to find out the geochemical background (GCB) in the area, systematic clustering and factor analysis were used to study the homology between HMs, and single-factor evaluation method was used to evaluate the ecological risks in the study area. The results of the study show that the ecological risk of the surface soil in the study area is relatively low, dominated by a planar distribution, with only a few high-risk points. The uneven distribution of $\mathrm{Hg}$ in the surface soil is affected by human activities to a certain extent. The ratio of the GCB of the geological unit area to the GCB of the whole area shows that the $\mathrm{Hg}$ content of the Qingshan Group and Dasheng Group geological units is higher, and the $\mathrm{Pb}$ content in the subvolcanic rock area is slightly higher. The ecological pollution risk in the study area is generally low, and only exists individual high-risk areas, distributed radially in densely populated areas.
\end{abstract}

Keywords: surface soil; heavy metals; geochemical characteristics; ecological risk assessment; Gaomi City

\section{Introduction}

Previous studies have shown that human activities have a strong disturbance effect on the distribution of HMs [1,2]. With the continuous use of chemical fertilizer, not only is the content of HMs in soil increasing, but the bioavailability of HMs in soil is also changing [3-7]. When the accumulation of HMs in soil exceeds the soil capacity, crop production will be reduced and the sustainable development of agriculture will be directly restricted [8,9]. Meanwhile, with the rapid development of the economy, and the acceleration of industrialization, urbanization, and agricultural modernization, the risk of farmland soil being polluted is increasing $[10,11]$. Studies have shown that land-use changes due to urban sprawl result in rising levels of impervious cover, which affects the vertical and vertical migration law of HMs [12]. Heavy metal elements in surface soil are not only controlled by human activities, but also affected by geological background, which can be distinguished according to land use types $[13,14]$. Rock is broken by weathering to form loose debris, called soil parent material, of which physical and chemical properties change, is the basic primitive material of soil. Previous studies have found that the soil parent material is an important natural source of HMs, which determines the initial heavy metal content in the soil [15-17]. In general, different geological units contain different 
types of soils. Indeed, even one individual geological unit may contain multiple types of soils. Soil heavy metal pollution is characterized by concealment, irreversibility, and long-term nature, which increases the difficulty of heavy metal pollution control [18]. HMs in the environment, soil, and water can eventually find their way into the human body by way of food chain, and therefore people consume heavy metal elements through diet every day $[19,20]$.

With the increasing use of land by human beings, soil environmental pollution is becoming more and more serious, especially heavy metal pollution in soil. It is necessary to study the GCB in the geological-unit perspective and in different types of land use areas.

Clear waters and green mountains are as good as mountains of gold and silver. Development at the expense of the environment has come to an end, and harmonious coexistence with the environment is the ideal long-term solution. From traditional agriculture to modern agriculture to the emergence of green agriculture, ecological agriculture and organic agriculture, soil quality is the key factor restricting agricultural transformation. Therefore, determining soil quality and heavy metal geochemical characteristics of agricultural land and assessing its ecological risk are prerequisites for effective land conservation and utilization. It is urgent to deal with the polluted cultivated land, protect the unpolluted cultivated land and develop different farming methods according to the condition of the land. The parameters of GCB are basic characteristic parameters in soil geochemical investigation and research, which represent the content level and changing rules of elements in soil [21].

Gaomi City is rich in geochemical and hydrogeochemical research foundation, but it mainly focuses on the source, migration, and enrichment law of fluorine in groundwater. However, as an important vegetable and grain planting base in Shandong Province, there are few investigations and studies on the distribution law of HMs in soil [22,23]. In this study, soil in Gaomi City is taken as the studied object, and the contents of eight types of $\mathrm{HMs}$, including $\mathrm{Cu}, \mathrm{Pb}, \mathrm{Zn}, \mathrm{Ni}, \mathrm{Cr}, \mathrm{Cd}, \mathrm{As}$, and $\mathrm{Hg}$, were tested, which are the necessary items for screening the risk of soil pollution on agricultural land [24,25]. Based on the test data, geochemical characteristics of HMs in soil of Gaomi were analyzed and ecological risk assessment was carried out according to China national standards of environmental quality standard for soils $[24,25]$. The purpose of this work is to find out the geochemical characteristics and ecological risk of HMs in surface soil of Gaomi City, so as to ensure the safety of agricultural products and formulate more reasonable plans for agricultural production and fertilizer use. The background values of heavy metal elements in the topsoil of the whole area, geological unit area, and land use type area were respectively studied.

\section{Research Background}

Gaomi City is located in Weifang City, Shandong Province, in the central part of Shandong Peninsula and the hinterland of Jiaolai Plain (Figure 1). Due to oscillatingupward crustal movement in the long geological history period, the rocks were exposed to weathering and denudation for a long time, forming the landform of low-lying hills and peneplain [22]. The main geological units include Mesozoic Laiyang group, Qingshan group, Latent volcanic rocks and Dasheng group; Cenozoic Dachan formation, Heituhu formation, Linyi formation and Yihe formation. The main rock types are pebbly sandstone, sandstone, siltstone, shale, pyroclastic rock, volcanic lava, conglomerate, and clay rock $[23,26]$. The Laiyang Group is a complex set of continental variegated clastic rocks with local volcanic rocks and a small amount of volcanic clastic deposits with fluviallacustrine facies. The Qingshan Group is a set of complex continental acidic volcanic rocks, intermediate-intermediate basic volcanic rocks, and volcano-sedimentary rocks. The lithology in the subvolcanic unit area is relatively single, which is rhyolite fused breccia tuff and glassy tuff formed by the eruption of acid volcanic magma. The Dasheng Group is a set of continental clastic rocks interbedded with volcanic rocks. The composition of Dazhan Formation belongs to the Middle Pleistocene and the Upper Pleistocene, and the sedimentary facies are eolian and alluvial, respectively. The Heituhu Formation is coastal lacustrine facies. The Dazhan Formation and the Heituhu Formation have different 
properties due to the different accumulation genesis. Both the Linyi and Yihe Formations are closely related to modern rivers, with the former as floodplain deposits and the latter as modern fluvial facies deposits [27-30]. In general, the terrain is higher in the south and lower in the north, with a maximum length of $60.1 \mathrm{~km}$ from north to south and a maximum width of $51.2 \mathrm{~km}$ from east to west, covering an area of $1525.70 \mathrm{~km}^{2}$. Gaomi City belongs to the warm temperate continental semi-humid climate in the monsoon area, with cold winter and hot summer, and four distinct seasons. The average annual precipitation is $689.1 \mathrm{~mm}$. The main land use type in the study area is cultivated land, followed by urban and village land. The region is dominated by grain planting, supplemented by vegetable planting. Among them, Xiazhuangdajingou leek is the local leek variety of Gaomi City, which was approved to use the public logo of agricultural product geographical indication in May 2012 [31]. Jiaohe potato is a specialty of Baicheng Town, Gaomi City, and is a product of China's national geographical indication [32].

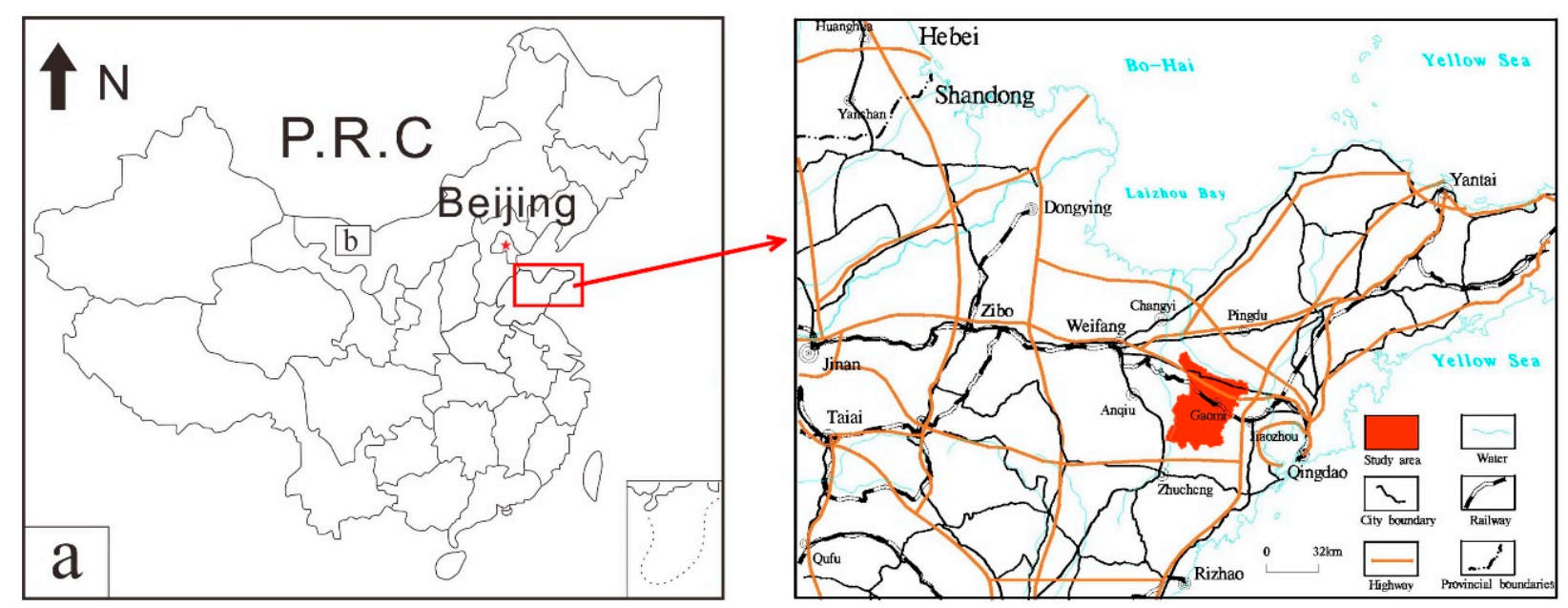

Figure 1. Location map of study area (a) Location of Shandong Peninsula (b) Location of study area.

\section{Samples and Methods}

\subsection{Sample Collection}

According to the "Specification for Geochemical Evaluation of Land Quality"(DZ/T 0295-2016) [33] and based on the latest 1:50,000 land use status map, the samples were mainly collected from agricultural land, other land samples were arranged according to the minimum requirements of the sampling density range, taking into account the uniform distribution of space. The design sampling unit was $1 \mathrm{~km}^{2}$ and the sampling density of soil samples is $4 \sim 8$ pieces $/ \mathrm{km}^{2}$, and the actual sampling average control density was 5.5 pieces $/ \mathrm{km}^{2}, 8197$ samples in total. In order to take into account the uniformity of spatial distribution, during sample collection, the preset sampling position was taken as the center of each sampling unit. Each sample consists of 4-6 samples mixed in equal quantities in equal quantities which comes from 1 main sampling point and 3-5 sub-sampling points, and the locations of the sub-sampling points were determined by radiating $50 \sim 100 \mathrm{~m}$ to the main sampling point.

The sampling depth of the topsoil is randomly between $0 \sim 20 \mathrm{~cm}$. The soil at each sampling point was crushed, the debris in samples were picked out, and the same amount of sample was mixed into different clean cloth sample bags, not less than $1 \mathrm{~kg}$ into an individual bag. All samples were collected and analyzed in the same way within one year in sunny weather. Sample collection and processing site are shown in Figure 2. 

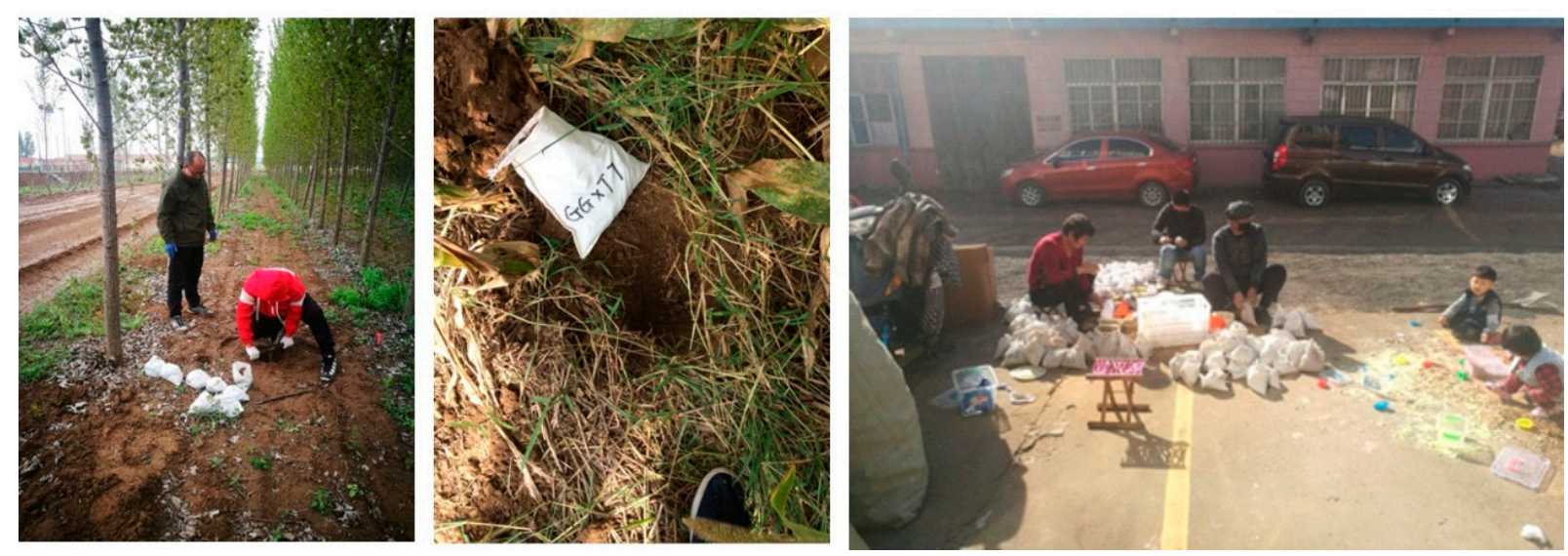

Figure 2. Pictures of sample collection and processing site.

\subsection{Samples Preparation and Testing}

The collected topsoil samples were hung in a cool place and naturally air-dried on the sample rack. After air-dried, they were spread on the sample making plate, crushed with a wooden stick, and sundries were removed. All the samples were mixed through a nylon sieve with a diameter of $2 \mathrm{~mm}$, weighed, and put into a plastic bottle at least $500 \mathrm{~g}$ for transfer to the laboratory for testing. During collection and processing, the samples did not make contact with metal utensils.

The sample preparation and testing were completed by the Experimental Test Center of the Fourth Geological and Mineral Exploration Institute of Shandong Province. The soil samples were processed to $0.074 \mathrm{~mm}$ by pollution-free geochemical exploration crushing machine, without shrinkage and screening, and were directly put into sample bags for testing. X-ray fluorescence spectrometry (XRF) was used to detect $\mathrm{Cu}, \mathrm{Pb}, \mathrm{Zn}, \mathrm{Ni}$, and $\mathrm{Cr}$, and inductively coupled plasma mass spectrometry (ICP-MS) was used to detect Cd. As was detected by atomic fluorescence spectrometry (AFS), and $\mathrm{Hg}$ was detected by steam generation cold atomic fluorescence spectrometry (AFS) $[24,25,34]$. The detection limit of the analytical method used for each element is $\mathrm{Cu}\left(1 \times 10^{-6}\right), \mathrm{Pb}\left(2 \times 10^{-6}\right), \mathrm{Zn}\left(4 \times 10^{-6}\right)$, $\mathrm{Ni}\left(2 \times 10^{-6}\right), \mathrm{Cr}\left(5 \times 10^{-6}\right), \mathrm{Cd}\left(0.02 \times 10^{-6}\right), \mathrm{As}\left(0.5 \times 10^{-6}\right), \mathrm{Hg}\left(0.5 \times 10^{-9}\right)$.

In order to ensure the accuracy and precision of experimental data, both internal quality control (IQC) and external quality control (EQC) were adopted. According to the "Technical Requirements for Analysis of Ecological Geochemical Evaluation Samples" (DD2005-03) [35], in the process of IQC 4 national first-level reference materials (GBW) of certified reference materials(CRM) were inserted for every 50 samples. In the process of EQC 2 external standard control samples of reference materials (RM) were inserted for every 50 samples. According to the statistical results of accuracy and precision of total analysis of soil elements, the qualified rate of accuracy and precision is $100 \%$, which meets test quality requirements of the "Specification of Land Quality Geochemical Assessment" (DZ/T 0295-2016) [33].

\subsection{Data Processing and Mapping}

Excel is used to eliminate the ultra-high and low values by iterative method, and the average value of element content is obtained to determine GCB. The systematic cluster analysis and factor analysis of 8 types of heavy metal elements in the topsoil of the study area were carried out by SPSS22.0. Spatial distribution mapping was carried out by universal Kriging method in MapGIS6.7 [36]. 


\section{Results-Geochemical Characteristics of HMs in Topsoil}

4.1. GCB of HMs in Topsoil

4.1.1. GCB of Heavy Metal Elements in the Topsoil of the Whole Region

The statistics of heavy metal element GCB in the topsoil are shown in Table 1. Among the eight $\mathrm{HMs}$, only the variation coefficients of $\mathrm{Pb}$ and $\mathrm{Cr}$ were less than 0.3 , showing a relatively uniform distribution. The variation coefficients of other heavy metal elements are all greater than 0.3 , showing a relatively obvious spatial distribution difference, among which the variation coefficient of $\mathrm{Hg}$ is the highest as 4.13, indicating that the spatial distribution difference of $\mathrm{Hg}$ element in the topsoil is extremely significant. In addition, by comparing the GCB of heavy metal elements in the topsoil of the study area with those in Weifang City [37] and Shandong Province [38], the GCB ratios (GCBRs) can be calculated. It is found that: (1) The GCBRs of HMs in the surface soil of the study area to those in Weifang City and Shandong Province are between $0.77 \sim 1.12,0.72 \sim 1.02$, respectively, indicating that the content of heavy metal elements in the topsoil of the study area is basically consistent with the average level of Weifang City and Shandong Province. (2) Six of the eight heavy metal elements in the study area were lower than GCB of Weifang and Shandong Province, $\mathrm{Pb}$ was similar to the GCB of Weifang and Shandong Province, and only As was slightly higher than that of Weifang. Comparing the median of $8 \mathrm{HMs}$ with the maximum allowable limits of heavy metal in soils of WHO and China (Table 2). It is demonstrated that the content of HMs in the topsoil of the whole region is under the limits.

Table 1. Table of heavy metal element geochemical parameters of surface soil in the study area.

\begin{tabular}{|c|c|c|c|c|c|c|c|c|}
\hline \multirow{2}{*}{ Element } & \multirow{2}{*}{ Median $/ 10^{-6}$} & \multirow{2}{*}{$\begin{array}{l}\text { Variation } \\
\text { Coefficient }\end{array}$} & \multirow{2}{*}{$\begin{array}{c}\text { Variation } \\
\text { Range/10 }\end{array}$} & \multicolumn{3}{|c|}{$\mathrm{GCB} / 10^{-6}$} & \multicolumn{2}{|c|}{ GCBRs } \\
\hline & & & & Gaomi & Weifang & Shandong & Gaomi/Weifang & Gaomi/Shandong \\
\hline $\mathrm{Cu}$ & 17.4 & 0.98 & $7.1-28.3$ & 17.7 & 21.2 & 22.6 & 0.83 & 0.78 \\
\hline $\mathrm{Zn}$ & 44.3 & 0.68 & $24.3-66.3$ & 45.3 & 58.5 & 63.3 & 0.77 & 0.72 \\
\hline $\mathrm{Pb}$ & 23.3 & 0.23 & $16.6-30$ & 23.3 & 22.9 & 23.6 & 1.02 & 0.99 \\
\hline As & 8.79 & 0.49 & $4.72-12.79$ & 8.75 & 7.8 & 8.6 & 1.12 & 1.02 \\
\hline $\mathrm{Cd}$ & 0.10 & 0.78 & $0.05-0.15$ & 0.10 & 0.114 & 0.132 & 0.88 & 0.76 \\
\hline $\mathrm{Cr}$ & 58.9 & 0.25 & $40.3-79$ & 59.6 & 65.3 & 62 & 0.91 & 0.96 \\
\hline $\mathrm{Ni}$ & 21.7 & 0.34 & $12.1-31.7$ & 21.9 & 26.9 & 27.1 & 0.81 & 0.81 \\
\hline $\mathrm{Hg}$ & 0.0252 & 4.13 & $0.01-0.05$ & 0.0266 & 0.032 & 0.031 & 0.83 & 0.86 \\
\hline
\end{tabular}

Table 2. Maximum Allowable Limits of Heavy Metal in Soils $\left(10^{-6}\right)$.

\begin{tabular}{ccccccccc}
\hline Organization/Country & $\mathbf{C u}$ & $\mathbf{Z n}$ & $\mathbf{P b}$ & $\mathbf{A s}$ & $\mathbf{C d}$ & $\mathbf{C r}$ & $\mathbf{N i}$ & $\mathbf{H g}$ \\
\hline WHO [20,39] & 100 & 300 & 100 & 20 & 3 & 100 & 50 & -8 \\
China [24,25] & 200 & 300 & 240 & 20 & 0.8 & 350 & 190 & 1 \\
Median & 17.4 & 44.3 & 23.3 & 8.79 & 0.10 & 58.9 & 21.7 & 0.0252 \\
\hline
\end{tabular}

\subsubsection{GCB of Heavy Metal Elements in Surface Soil of Different Geological Unit Areas}

A total of seven geological units were divided, including Laiyang Formation, Qiangshan Formation, Qianhuoshan Formation, Dasheng Formation, Dazhan Formation, Heituhu Formation, and Linyi-Yihe Formation. Areas of each formation are shown in Table 3. The soil GCB of 7 types of geological units were listed in Table 4. Soil GCBRs between each geological unit with the whole area could also be found in Table 4. A visual comparison of GCB and GCBRs of each geological unit are shown in Figure 3.

Table 3. Statistical table of geological unit division in the study area.

\begin{tabular}{cccccccc}
\hline $\begin{array}{c}\text { Geological } \\
\text { Unit }\end{array}$ & $\begin{array}{c}\text { Laiyang } \\
\text { Group }\end{array}$ & $\begin{array}{c}\text { Qingshan } \\
\text { Group }\end{array}$ & $\begin{array}{c}\text { Latent Volcanic } \\
\text { Rocks }\end{array}$ & $\begin{array}{c}\text { Dasheng } \\
\text { Group }\end{array}$ & $\begin{array}{c}\text { Dazhan } \\
\text { Formation }\end{array}$ & $\begin{array}{c}\text { Heituhu } \\
\text { Formation }\end{array}$ & $\begin{array}{c}\text { Linyi-Yihe } \\
\text { Formation }\end{array}$ \\
\hline Area $\left(\mathrm{km}^{2}\right)$ & 423.6 & 11.8 & 8.50 & 21.8 & 185.0 & 647.0 & 227.9 \\
Percentage $(\%)$ & 27.76 & 0.78 & 0.56 & 1.43 & 12.13 & 42.41 & 14.94 \\
\hline
\end{tabular}


Table 4. Statistical table of soil GCBs and GCBRs of each geological unit area.

\begin{tabular}{|c|c|c|c|c|c|c|c|c|c|}
\hline \multirow{2}{*}{\multicolumn{2}{|c|}{ Geological Unit }} & \multicolumn{8}{|c|}{ Elements } \\
\hline & & \multirow{3}{*}{$\begin{array}{c}\mathrm{Cu} \\
16.10 \\
0.91\end{array}$} & \multirow{3}{*}{$\begin{array}{c}\mathbf{Z n} \\
41.00 \\
0.91\end{array}$} & \multirow{3}{*}{$\begin{array}{c}\mathbf{P b} \\
23.20 \\
1.00\end{array}$} & \multirow{3}{*}{$\begin{array}{c}\text { As } \\
8.53 \\
0.97\end{array}$} & \multirow{3}{*}{$\begin{array}{c}\text { Cd } \\
0.09 \\
0.90\end{array}$} & \multirow{3}{*}{$\begin{array}{c}\text { Cr } \\
58.70 \\
0.98\end{array}$} & \multirow{3}{*}{$\begin{array}{c}\mathbf{N i} \\
21.30 \\
0.97\end{array}$} & \multirow{3}{*}{$\begin{array}{c}\mathbf{H g} \\
0.028 \\
1.05\end{array}$} \\
\hline & $\mathrm{GCB} / 10^{-6}$ & & & & & & & & \\
\hline La1yang Group & GCBRs & & & & & & & & \\
\hline \multirow{2}{*}{ Qingshan Group } & $\mathrm{GCB} / 10^{-6}$ & 18.30 & 49.10 & 24.20 & 8.57 & 0.11 & 60.20 & 22.70 & 0.040 \\
\hline & GCBRs & 1.03 & 1.08 & 1.04 & 0.98 & 1.10 & 1.01 & 1.04 & 1.48 \\
\hline \multirow{2}{*}{ Latent volcanic rocks } & $\mathrm{GCB} / 10^{-6}$ & 17.00 & 45.50 & 29.60 & 8.86 & 0.10 & 54.80 & 21.80 & 0.028 \\
\hline & GCBRs & 0.96 & 1.00 & 1.27 & 1.01 & 1.00 & 0.92 & 1.00 & 1.05 \\
\hline \multirow{2}{*}{ Dasheng Group } & $\mathrm{GCB} / 10^{-6}$ & 15.10 & 43.80 & 23.40 & 8.83 & 0.10 & 58.90 & 22.00 & 0.034 \\
\hline & GCBRs & 0.85 & 0.97 & 1.00 & 1.01 & 1.00 & 0.99 & 1.00 & 1.29 \\
\hline \multirow{2}{*}{ Dazhan Formation } & $\mathrm{GCB} / 10^{-6}$ & 19.30 & 46.20 & 22.50 & 9.33 & 0.10 & 58.70 & 22.40 & 0.023 \\
\hline & GCBRs & 1.09 & 1.02 & 0.97 & 1.07 & 1.00 & 0.98 & 1.02 & 0.87 \\
\hline \multirow{2}{*}{ Heituhu Formation } & $\mathrm{GCB} / 10^{-6}$ & 19.10 & 49.00 & 23.90 & 9.00 & 0.10 & 61.80 & 23.50 & 0.027 \\
\hline & GCBRs & 1.08 & 1.08 & 1.03 & 1.03 & 1.00 & 1.04 & 1.07 & 1.02 \\
\hline \multirow{2}{*}{ Linyi-Yihe Formation } & $\mathrm{GCB} / 10^{-6}$ & 15.80 & 41.00 & 21.90 & 7.94 & 0.08 & 56.20 & 19.10 & 0.024 \\
\hline & GCBRs & 0.89 & 0.91 & 0.94 & 0.91 & 0.80 & 0.94 & 0.87 & 0.89 \\
\hline
\end{tabular}

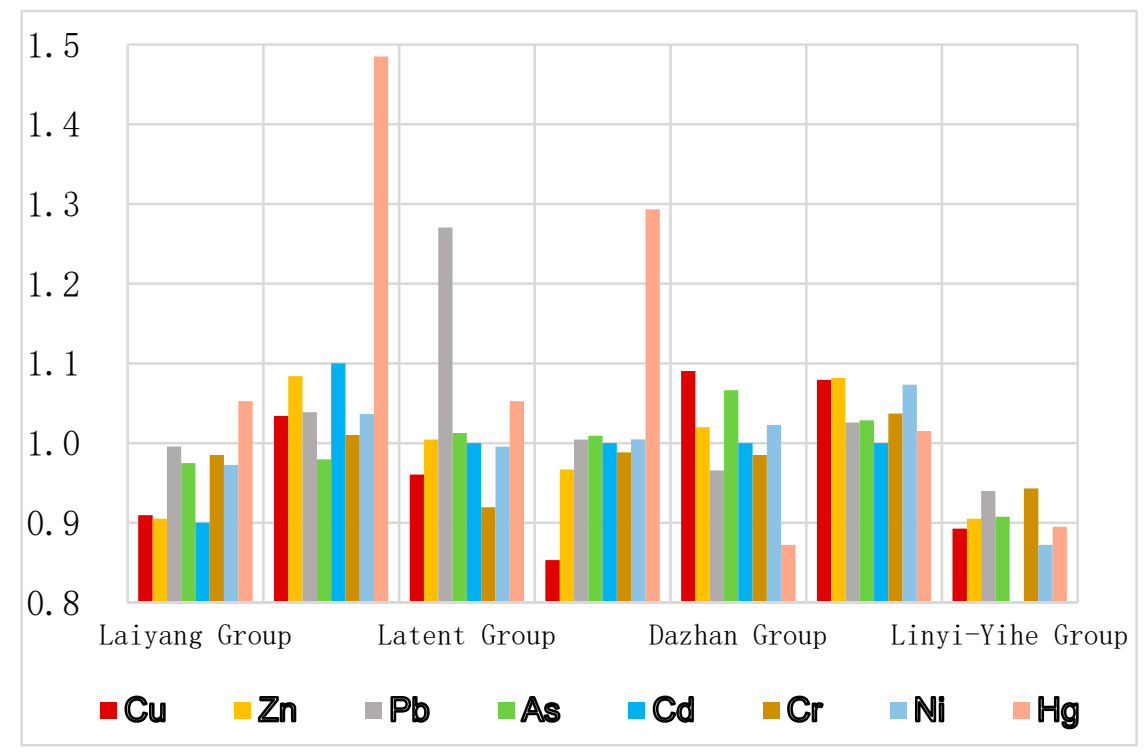

Figure 3. Bar chart of GCBRs.

As shown in Table 4 and Figure 3. Through analysis, it is found that the heavy metal elements in the topsoil of Laiyang Group are close to the background values of the whole region, with the GCBRs of $0.90 \sim 1.05$. The ratio of $\mathrm{Hg}$ to the background values of the whole region is relatively high (GCBRs 1.48), which is the main distribution area of most heavy metal anomalies. Qingshan Group, except for As (GCBRs 0.98), is relatively lower than others. Moreover, excluding the GCBRs of $\mathrm{Pb}(1.27)$ as obviously higher, the other elements in this geological unit are close to the background value of the whole area (GCBRs 0.92 1.05), which is the main distribution area of $\mathrm{Pb}$ anomaly. In Dasheng Group, except $\mathrm{Cu}$ (GCBRs 0.85) and Hg (GCBRs 1.29), other elements are close to the background values of the whole region (0.97 1.01). Due to the differences of accumulation origin and properties of Dazhan Formation and Heituhu Formation, it is found that, except Hg in the Dazhan Formation, which is lower than the background value of the whole area (GCBRs 0.87), the heavy metal elements in the topsoil in these two units are close to and slightly higher than the background values of the whole area, especially higher than the background value of the whole area in the Heituhu Formation. Compared with the background values of the 
whole region, the heavy metal elements in the topsoil of Linyi and Yihe Formations are lower or even significantly lower, which is the main distribution area of negative anomaly, indicating that there is no heavy metal pollution source at the source and banks of the river. Based on the comprehensive analysis of the whole region, it is found that the background values of heavy metal elements in different geological unit areas have a good correlation with the background values of the whole region, and only show anisotropy at a few points, indicating that the content of heavy metal elements in the topsoil of the whole region is mainly affected by the geological background.

4.1.3. GCB of Heavy Metal Elements in the Surface Soil of Different Types of Land Use Areas

By studying the distribution of HMs in different types of land, we can analyze the influence of different human activities on the distribution of HMs. According to the land survey results of Weifang City in 2015, the land use types in the study area were divided into eight types and their soil GCBs were statistically analyzed and compared with the GCB of the whole area (Table 5 and Figure 4). Soil GCB ratios between each type of land use area with the whole area (GCBRs) could also be found in Table 5. A visual comparison of GCB and GCBRs of each geological unit is shown in Figure 4.

Table 5. Statistical table of soil GCBs in different types of land use areas.

\begin{tabular}{|c|c|c|c|c|c|c|c|c|c|}
\hline \multirow{2}{*}{ Land Use Types } & & \multicolumn{8}{|c|}{ Elements } \\
\hline & & $\mathrm{Cu}$ & $\mathrm{Zn}$ & $\mathrm{Pb}$ & As & $\mathrm{Cd}$ & $\mathrm{Cr}$ & $\mathrm{Ni}$ & $\mathrm{Hg}$ \\
\hline \multirow{2}{*}{ cultivated land } & $\mathrm{GCB} / 10^{-6}$ & 17.8 & 45.3 & 23.4 & 8.93 & 0.1 & 59.9 & 22.1 & 0.0268 \\
\hline & GCBRs & 1.01 & 1.00 & 1.00 & 1.02 & 1.00 & 1.01 & 1.01 & 1.01 \\
\hline \multirow{2}{*}{ Garden } & $\mathrm{GCB} / 10^{-6}$ & 21.9 & 47.8 & 23.5 & 8.94 & 0.11 & 58.5 & 21 & 0.0313 \\
\hline & GCBRs & 1.24 & 1.06 & 1.01 & 1.02 & 1.10 & 0.98 & 0.96 & 1.18 \\
\hline \multirow{2}{*}{ Woodland } & $\mathrm{GCB} / 10^{-6}$ & 16 & 42.1 & 22.2 & 8.06 & 0.09 & 58 & 21 & 0.0258 \\
\hline & GCBRs & 0.90 & 0.93 & 0.95 & 0.92 & 0.90 & 0.97 & 0.96 & 0.97 \\
\hline \multirow{2}{*}{ Grass land } & $\mathrm{GCB} / 10^{-6}$ & 15.6 & 42.6 & 22.1 & 7.17 & 0.09 & 61 & 21.5 & 0.0197 \\
\hline & GCBRs & 0.88 & 0.94 & 0.95 & 0.82 & 0.90 & 1.02 & 0.98 & 0.74 \\
\hline \multirow{2}{*}{ Transportation land } & $\mathrm{GCB} / 10^{-6}$ & 20.8 & 61.1 & 24.1 & 7.97 & 0.12 & 63.1 & 22.5 & 0.0256 \\
\hline & GCBRs & 1.18 & 1.35 & 1.03 & 0.91 & 1.20 & 1.06 & 1.03 & 0.96 \\
\hline \multirow{2}{*}{$\begin{array}{c}\text { Waters and water } \\
\text { conservancy facilities land }\end{array}$} & $\mathrm{GCB} / 10^{-6}$ & 17.2 & 45.7 & 22.5 & 8.08 & 0.09 & 62 & 23.2 & 0.018 \\
\hline & GCBRs & 0.97 & 1.01 & 0.97 & 0.92 & 0.90 & 1.04 & 1.06 & 0.68 \\
\hline \multirow{2}{*}{$\begin{array}{c}\text { Towns, villages and } \\
\text { industrial and mining lands }\end{array}$} & $\mathrm{GCB} / 10^{-6}$ & 21.3 & 64.6 & 27.4 & 7.52 & 0.13 & 59.3 & 22.3 & 0.0387 \\
\hline & GCBRs & 1.20 & 1.43 & 1.18 & 0.86 & 1.30 & 0.99 & 1.02 & 1.45 \\
\hline \multirow{2}{*}{ Others } & $\mathrm{GCB} / 10^{-6}$ & 18.5 & 49.9 & 23.5 & 8.3 & 0.1 & 58.4 & 21.4 & 0.0263 \\
\hline & GCBRs & 1.05 & 1.10 & 1.01 & 0.95 & 1.00 & 0.98 & 0.98 & 0.99 \\
\hline
\end{tabular}

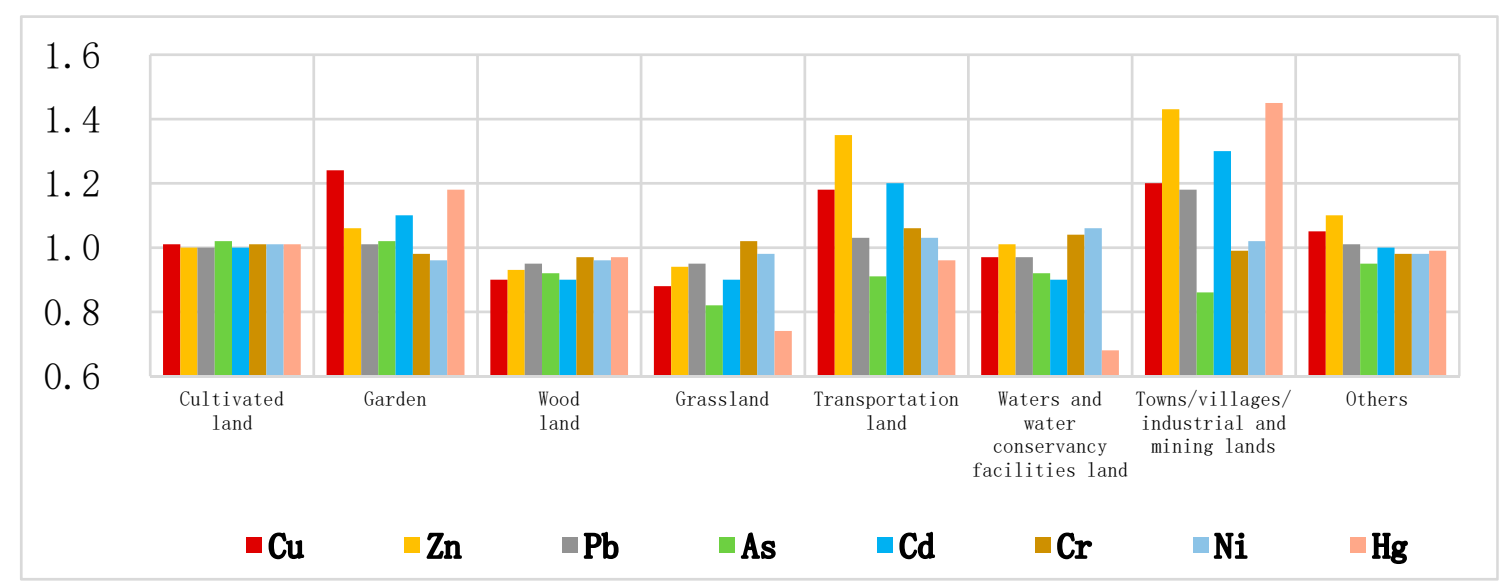

Figure 4. Bar chart of GCBRs. 
The land use type in the study area is mainly cultivated land, accounting for $70.90 \%$ of the total area. The background value of HMs in the surface soil of cultivated land is very close to the background value of the whole area, indicating that agricultural activities in the study area have a weak influence on the changes of heavy metal contents in the topsoil. The area of the garden occupies $12.00 \%$ of the whole area. $\mathrm{Cu}, \mathrm{Hg}$, and $\mathrm{Cd}$ in this type of area are significantly higher than the background values of the whole area, which are $1.24,1.18$ and 1.10, respectively. Other elements are close to the background values of the whole area (the GCBRs is 0.96 1.06). The results indicate that the agricultural production activities in the garden had a slightly more significant effect on the content of HMs in the topsoil than that in the cultivated land. The background values of most heavy metal elements in woodland, grassland, water area, and water conservancy facilities land are lower than the background values of the whole area, and a few heavy metal elements are close to or slightly higher than the background values of the whole area, which reflects that these land use types are less affected by human disturbance. In the transportation land, $\mathrm{Zn}, \mathrm{Cu}$, and $\mathrm{Cd}$ are significantly higher than the background values of the whole area, while $\mathrm{Pb}, \mathrm{Cr}$, and $\mathrm{Ni}$ are slightly higher than the background values of the whole area. These anomalies are mainly distributed on both sides of the highway, and may even form pollution zones. $\mathrm{Cu}, \mathrm{Pb}, \mathrm{Zn}, \mathrm{Cd}$, and $\mathrm{Hg}$ in towns, villages and industrial and mining land were significantly higher than the background values of the whole area, while $\mathrm{Ni}$ was slightly higher than the background values of the whole area.

Therefore, it can be seen that human activities are an important factor affecting the change of the content of HMs in topsoil, especially the industry, mining industry and transportation industry. In transportation, automobile exhaust and tire wear may produce dust with HMs, which enters the soil through settling, increasing the content of HMs in the topsoil and forming anomalies $[14,40]$.

\subsection{Homologous-Cluster Analysis of Heavy Metal Elements \\ 4.2.1. Cluster Analysis}

In the cluster analysis, elements with symbiotic or similar genesis should have sufficient similarity or homogeneity, while elements with large differences or dissimilar genesis should have great heterogeneity [41]. The heavy metal elements in root soil samples were classified according to similarity degree by system clustering method, and the possible symbiotic relationship or genetic relationship among these heavy metal elements were analyzed. As shown in Figure 5, when the confidence level is five, the eight HMs can be divided into seven categories. Then, only nickel and cadmium are divided into the same group, and other HMs form a group respectively. When the confidence is 10, the eight HMs can be divided into six categories. The first category is $\mathrm{Ni}$ and $\mathrm{Cr}$, the second category is $\mathrm{Cu}$ and $\mathrm{Zn}$, and other four HMs form a different group. When the confidence is 20, the eight heavy metal elements can be divided into four categories. The first category is $\mathrm{Ni}$ and $\mathrm{Cr}$, the second category is $\mathrm{Cu}, \mathrm{Zn}, \mathrm{Cd}$, and $\mathrm{Pb}$, while the third and fourth categories are $\mathrm{As}$ and $\mathrm{Hg}$, respectively. The elements in each category are correlated with each other, displaying high homology.

\subsubsection{Homologous Analysis}

As shown in Table 6, main causes of the eight elements are listed. The dimensionality reduction of heavy metal element data through principal factor analysis can better discover the original information rules and excavate the homology of heavy metal elements.

In order to obtain the main factor, the eigenvalue and corresponding eigenvector of the correlation matrix are calculated, and the cumulative percentage is obtained according to the percentage of eigenvalue (variance contribution). The factors with a large eigenvalue and cumulative contribution rate of more than $80 \%$ are selected as the main factors. According to the eigenvalue calculation results the eight heavy metal elements in the study area can be extracted as three major factors, (Table 7), and the heavy metal elements in each major factor have similar sources or homology [42]. According to the extraction results 
(Table 8), the three main factors can represent $63.146 \%$ of the cumulative contribution of the eight HMs, and the characteristic roots are all greater than 1 . That is to say, the three main factors can basically represent the distribution characteristics of the eight HMs. Taking the factor load greater than the constant value of 0.5 as the criterion, the combined characteristics of the eight heavy metal elements in the study area were obtained. The characteristic root percentage of the main factor 1 was $26.641 \%$, and its variables included $\mathrm{Cd}, \mathrm{Cu}, \mathrm{Pb}$, and $\mathrm{Zn}$. The characteristic root percentage of the main factor 2 was $22.401 \%$, and its variables included $\mathrm{Ni}$ and $\mathrm{Cr}$. The characteristic root percentage of the main factor 3 was $14.105 \%$, and its variables included $\mathrm{Hg}$ and As. The results of principal factor analysis are basically consistent with those of cluster analysis.

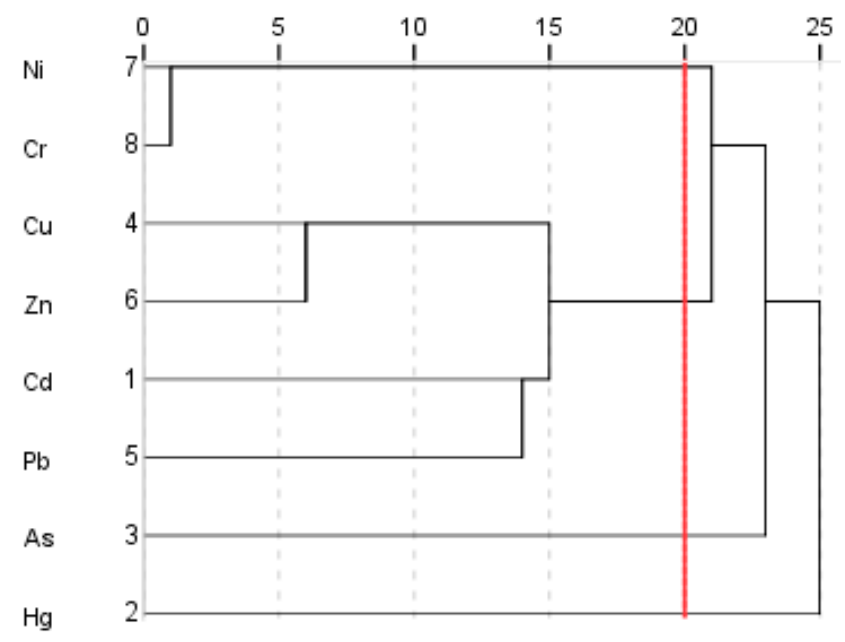

Figure 5. Cluster spectrum of HMs.

Table 6. Main causes of the eight elements.

\begin{tabular}{ccc}
\hline Elements & Main Causes & References \\
\hline $\mathrm{Cd}$ & Smelting of non-ferrous metals, disposal of cadmium-containing wastes. \\
$\mathrm{Cu}$ & Smelting emissions soot, industrial coal, automobile exhaust. \\
$\mathrm{Pb}$ & Gas from gasoline combustion, lead paint, smelting, casting. \\
$\mathrm{Zn}$ & Smelting, waste incineration, rubber tire wear. \\
$\mathrm{Ni}$ & Smelting, roasting, automobile exhaust. \\
$\mathrm{Cr}$ & Metal processing, electroplating, tanning, coal burning, oil burning. \\
$\mathrm{Hg}$ & Coal-fired power plants, mining and processing of related mineral materials. \\
$\mathrm{As}$ & Industrial production, use of arsenic-containing pesticides, coal burning. \\
\hline
\end{tabular}

The high-score region of main factor 1 (Figure 6a) is mainly distributed in the densely populated and industrially developed areas such as Gaomi urban area and its surrounding towns, indicating that human activities are the main reason for the high content of each element of main factor 1 . The $\mathrm{Ni}$ and $\mathrm{Cr}$ in the main factor 2 belong to the iron group elements, which are difficult to migrate, and are generally attached to the soil parent material in the form of secondary minerals. From the distribution characteristics (Figure 6b), it can be seen that the high-score zone is not quite consistent with the densely populated areas of human activities, while the low-score zone is mainly distributed along the Jiaohe River, Wulong River and the alluvial zones on both sides of the river. This is mainly because the heavy metal elements are carried away by the current and replaced by river sediments under the scouring action of the river. Therefore, it can be concluded that the main factor 2 is affected by the geological background and geomorphic form at the same time. The main factor 3 high-yield area (Figure 6c) mainly presents a point-source distribution, which is relatively concentrated in the Gaomi urban area and its surrounding areas, indicating that it may be significantly affected by human activities. 
Table 7. Common factor eigenvalue calculation.

\begin{tabular}{cccccc}
\hline Variable & $\begin{array}{c}\text { Initial } \\
\text { Value }\end{array}$ & $\begin{array}{c}\text { Cumulative } \\
\text { Characteristic Root } \%\end{array}$ & Variable & $\begin{array}{c}\text { Initial } \\
\text { Value }\end{array}$ & $\begin{array}{c}\text { Cumulative } \\
\text { Characteristic Root\% }\end{array}$ \\
\hline $\mathrm{Cd}$ & 1.000 & 0.628 & $\mathrm{Ni}$ & 1.000 & 0.840 \\
$\mathrm{Cu}$ & 1.000 & 0.771 & $\mathrm{Cr}$ & 1.000 & 0.741 \\
$\mathrm{~Pb}$ & 1.000 & 0.654 & $\mathrm{Hg}$ & 1.000 & 0.989 \\
$\mathrm{Zn}$ & 1.000 & 0.793 & $\mathrm{As}$ & 1.000 & 0.970 \\
\hline
\end{tabular}

Table 8. Heavy metal main factor loading matrix and factor extraction results in the study area.

\begin{tabular}{cccc}
\hline Variable & Main Factor 1 & Main Factor 2 & Main Factor 3 \\
\hline $\mathrm{Cd}$ & 0.652 & -0.007 & 0.289 \\
$\mathrm{Hg}$ & 0.089 & -0.137 & 0.723 \\
$\mathrm{As}$ & -0.003 & 0.264 & 0.592 \\
$\mathrm{Cu}$ & 0.784 & 0.113 & -0.134 \\
$\mathrm{~Pb}$ & 0.555 & 0.186 & 0.381 \\
$\mathrm{Zn}$ & 0.859 & 0.145 & -0.027 \\
$\mathrm{Ni}$ & 0.147 & 0.907 & 0.075 \\
$\mathrm{Cr}$ & 0.127 & 0.901 & 0.035 \\
Characteristic root & 2.131 & 1.792 & 1.128 \\
Percentage of characteristic root/\% & 26.641 & 22.401 & 14.105 \\
Cumulative percentage/\% & 26.641 & 49.041 & 63.146 \\
\hline
\end{tabular}
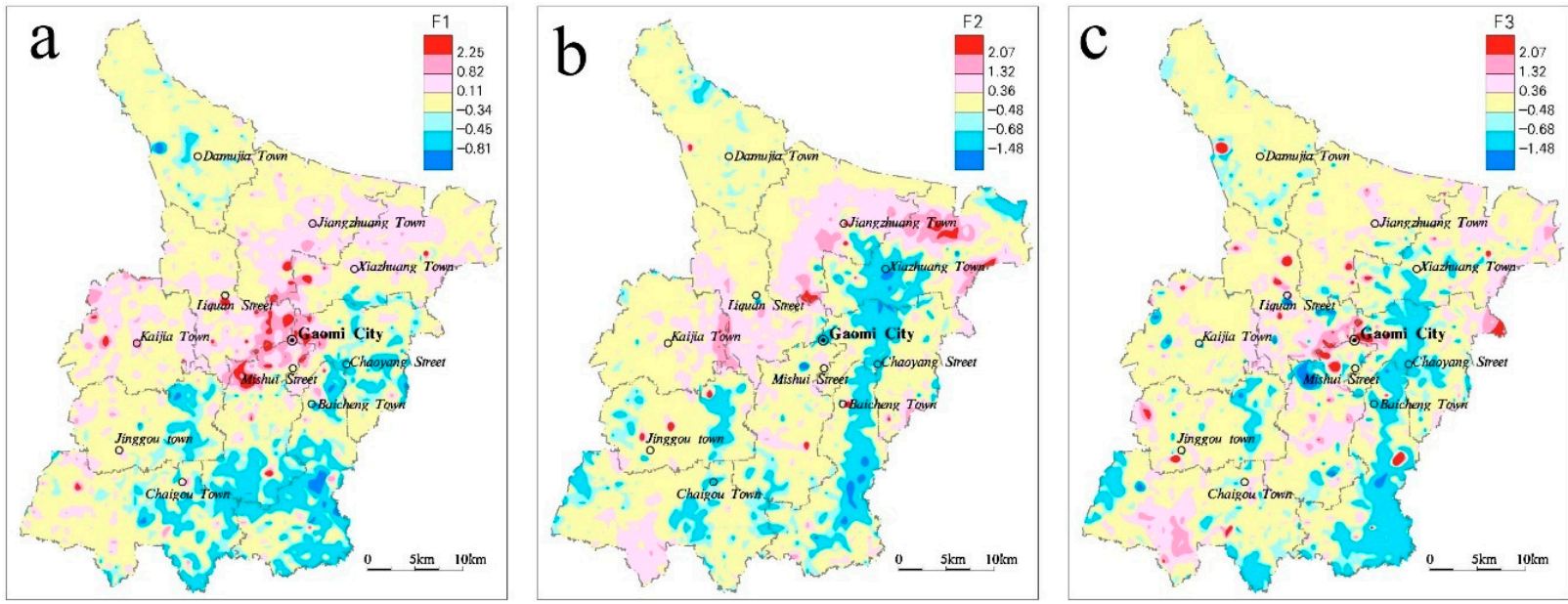

Figure 6. Score contour map for three main factors (a) factor 1 (b) factor 2 (c) factor 3.

\section{Ecological Risk Assessment}

\subsection{Ecological Risk Assessment Methods}

Single-factor ecological risk assessment was carried out as shown in Table 9, combining the risk screening values Si and risk control values Gi of eight HMs given in the risk control standard of soil pollution in agricultural land [24] or the risk control standard of soil pollution in construction land [25].

Table 9. Boundary of single factor ecological risk level division.

\begin{tabular}{cccc}
\hline Level & First-Class & Second-Class & Third-Class \\
\hline Pollution risk & Risk-free & Risk-controllable & High risk \\
Classification criterion & $C_{i} \leq S_{i}$ & $S_{i}<C_{i} \leq G i$ & $C_{i}>G_{i}$ \\
\hline
\end{tabular}

In addition, the method of potential ecological risk index (RI) was also used in this paper to evaluate the ecological risk of HMs. This method includes two concepts, namely 
the single factor potential ecological risk coefficient $E_{i}$ and potential ecological risk index RI. The calculation formulas are as follows:

$$
\begin{gathered}
E_{i}=T_{i} \times\left(C_{i} / C_{0}\right) \\
\mathrm{RI}=\sum E_{i}
\end{gathered}
$$

where $T_{i}$ is the toxicity coefficient of heavy metal $i$ (see Table 10), $C_{i}$ is the content of heavy metal $i$ in topsoil, and $C_{0}$ is the background value of heavy metal elements in the topsoil of the study area $[47,48]$.

Table 10. Toxicity coefficient $\left(T_{i}\right)$ of heavy metal.

\begin{tabular}{ccccccccc}
\hline Element & $\mathbf{Z n}$ & $\mathbf{C r}$ & $\mathbf{C u}$ & $\mathbf{P b}$ & $\mathbf{N i}$ & $\mathbf{A s}$ & $\mathbf{C d}$ & $\mathbf{H g}$ \\
\hline $\begin{array}{c}\text { Toxicity } \\
\text { coefficient }\end{array}$ & 1 & 2 & 5 & 5 & 5 & 10 & 30 & 40 \\
\hline
\end{tabular}

Through calculation, ecological risks are classified according to the standard in Table 11, and the pollution degree is divided into five grades: mild, moderate, strong, strong, and extremely strong.

Table 11. Potential ecological risk assessment criteria.

\begin{tabular}{cccc}
\hline $\begin{array}{c}\text { Single Factor Potential } \\
\text { Ecological Risk Coefficient }\end{array}$ & $\begin{array}{c}\text { Potential Ecological } \\
\text { Risk Index }\end{array}$ & Pollution Level & References \\
\hline$E_{i}<40$ & $\mathrm{RI}<150$ & Mild & \\
$40 \leq E_{i}<80$ & $150 \leq \mathrm{RI}<300$ & Moderate & \\
$80 \leq E_{i}<160$ & $300 \leq \mathrm{RI}<600$ & Strong & {$[44,49]$} \\
$160 \leq E_{i}<320$ & $\mathrm{RI} \geq 600$ & Very strong & \\
$E_{i} \geq 320$ & $/$ & Extremely strong & \\
\hline
\end{tabular}

\subsection{Ecological Risk Assessment Results}

In the process of the single factor ecological risk assessment, the evaluation unit is drawn according to the sampling unit $\left(1 \mathrm{~km}^{2}\right)$. Based on the single factor ecological risk assessment level, the comprehensive ecological risk assessment level of each assessment unit is equal to the worst level of single factor assessment. The evaluation results are shown in Table 12 and Figure 7a. It can be seen that the topsoil in the study area is mainly risk-free. The area of controllable risk is small $\left(9.71 \mathrm{~km}^{2}\right)$, which is mainly caused by the excess of the risk screening values of $\mathrm{Zn}, \mathrm{Cu}, \mathrm{Cd}$, and $\mathrm{Ni}$. However, the area with high risk was only $0.63 \mathrm{~km}^{2}$, which was caused by $\mathrm{As}, \mathrm{Hg}$, and $\mathrm{Cd}$ exceeding the risk control value in a small range.

Table 12. Statistical table of single factor and comprehensive area of heavy metal pollution in topsoil.

\begin{tabular}{cccc}
\hline \multirow{2}{*}{ Element } & \multicolumn{3}{c}{ Area/ $\mathbf{k m}^{\mathbf{2}}$} \\
\cline { 2 - 4 } & Risk-Free & Risk-Controllable & High Risk \\
\hline $\mathrm{Pb}$ & 1525.64 & 0.07 & $/$ \\
$\mathrm{Zn}$ & 1525.15 & 0.56 & $/$ \\
$\mathrm{As}$ & 1525.41 & 0.02 & 0.28 \\
$\mathrm{Hg}$ & 1525.67 & 0.03 & 0.002 \\
$\mathrm{Cu}$ & 1519.08 & 6.62 & $/$ \\
$\mathrm{Cd}$ & 1522.94 & 2.30 & 0.46 \\
$\mathrm{Ni}$ & 1525.13 & 0.57 & $/$ \\
$\mathrm{Cr}$ & 1525.58 & 0.13 & $\mathbf{0 . 6 3}$ \\
\hline
\end{tabular}



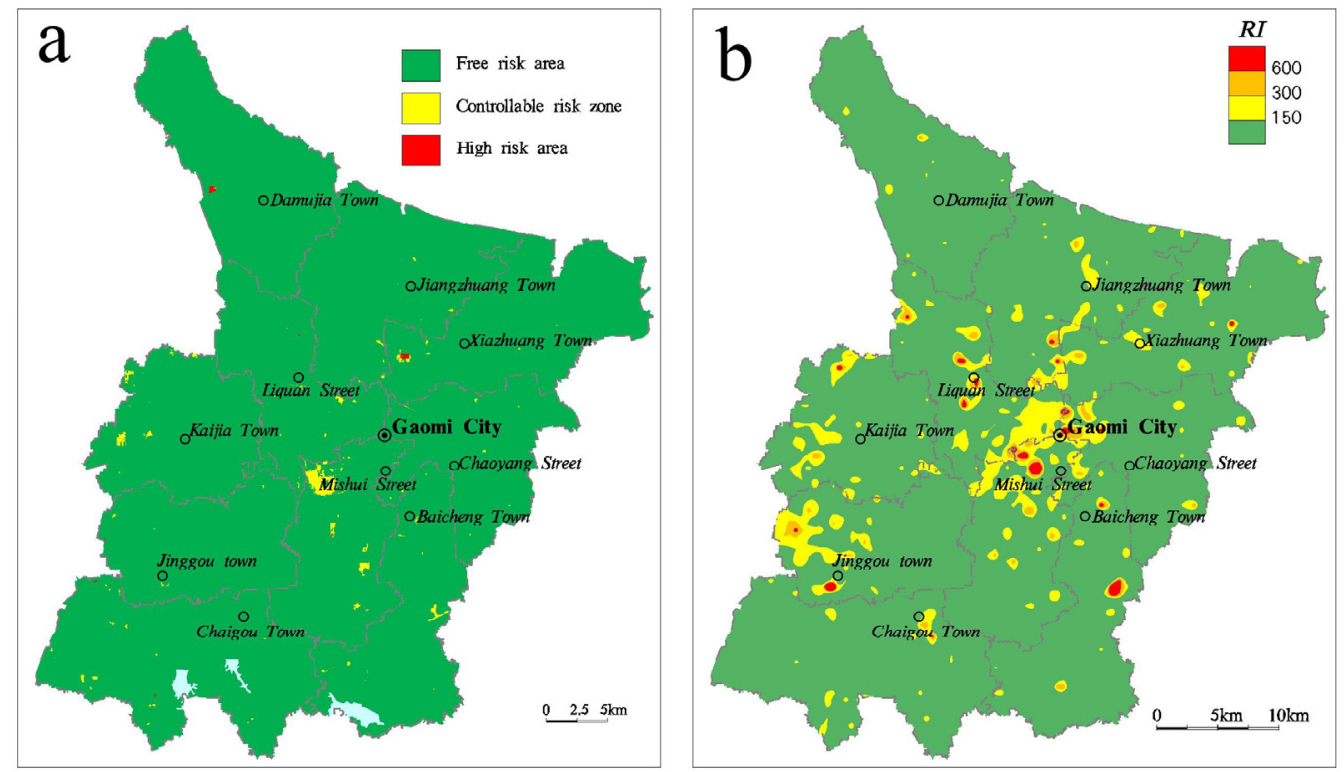

Figure 7. Comprehensive distribution map of study area (a) Comprehensive grade map of ecological risk assessment of HMs in topsoil (b) Spatial distribution map of Potential risk index of HMs in topsoil.

The calculation results of single factor potential ecological risk coefficient $E_{i}$ are shown in Table 13. Except for $\mathrm{Hg}$, the average value of other single factor $E_{i}$ is lower than 40 , indicating a low degree of potential ecological pollution risk of single factor. The sum of EI is calculated to obtain the potential ecological risk index RI, and top draw the spatial distribution map of the potential ecological risk index by combining the sampling points (see Figure 7b). It was found that the area with RI value lower than 150 was $1386.44 \mathrm{~km}^{2}$, accounting for $90.87 \%$ of the total area, and the ecological pollution risk was low. The area with moderate pollution is $117.61 \mathrm{~km}^{2}$, accounting for $7.71 \%$, which is mainly distributed around Gaomi urban area and some densely populated areas in towns and villages. The areas with high and strong pollution levels were $15.70 \mathrm{~km}^{2}$ and $5.95 \mathrm{~km}^{2}$, accounting for $1.03 \%$ and $0.39 \%$, respectively. They were distributed in densely populated areas as point sources, mainly caused by the high point values of $\mathrm{Hg}$ and $\mathrm{Cd}$. The point source pollution needs to be paid attention to.

Table 13. Single factor potential risk factor of HMs in topsoil.

\begin{tabular}{|c|c|c|c|}
\hline \multirow{2}{*}{ Single Factor } & \multicolumn{3}{|c|}{ Potential Ecological Risk Coefficient- $E_{i}$} \\
\hline & Average & Minimum & Maximum \\
\hline $\mathrm{Cd}$ & 31.57 & 6.00 & 1044.00 \\
\hline $\mathrm{Hg}$ & 56.96 & 4.51 & 14424.06 \\
\hline As & 10.15 & 2.29 & 382.45 \\
\hline $\mathrm{Cu}$ & 5.72 & 0.56 & 216.81 \\
\hline $\mathrm{Pb}$ & 5.08 & 2.15 & 34.01 \\
\hline $\mathrm{Zn}$ & 1.08 & 0.15 & 38.31 \\
\hline $\mathrm{Ni}$ & 5.12 & 0.89 & 64.47 \\
\hline $\mathrm{Cr}$ & 2.03 & 0.58 & 16.43 \\
\hline
\end{tabular}

\section{Conclusions}

In the Gaomi City, statistical methods were used to find out the geochemical background values, systematic clustering and factor analysis were used to study the homology between heavy metal ions, and single-factor evaluation methods were used to evaluate the ecological risks in the study area. Several certain conclusions were obtained as follows.

(1) Compared with the GCB of Weifang, As is higher, $\mathrm{Pb}$ is similar, and others are lower. Compared with the GCB Shandong Province, $\mathrm{Pb}$, As, and $\mathrm{Cr}$ are similar, 
whereas others are lower. The GCB of different geological units and land use types are different, indicating that the distribution of heavy metal elements is affected by geological background and human activities.

(2) The homology cluster analysis showed that the $\mathrm{Cd}, \mathrm{Cu}, \mathrm{Pb}$, and $\mathrm{Zn}$ in the topsoil had similar origin or homology, which were mainly affected by human activities. $\mathrm{Ni}$ and $\mathrm{Cr}$ have similar origin or homology, and are affected by geological background, geomorphologic form and human activities. $\mathrm{Hg}$ and As had similar origin or homology, and the high value area showed radial distribution, which may be related to industrial and mining enterprises.

(3) According to the evaluation of ecological risk based on soil risk management and control standards, the study area is dominated by riskless soils, but there are also some soils with high risks. The average potential ecological risk coefficient of $\mathrm{Hg}$ reached moderate pollution degree. Based on an evaluation of potential ecological risk index, the surface soil in the study area is found to contain light pollution, with an area of more than $90 \%$. Meanwhile, there are also moderate pollution, strong pollution, and very strong pollution, among which strong pollution and very strong pollution areas are small, displaying a point-source distribution located in densely populated areas.

Author Contributions: Conceptualization, S.W., and Z.G.; methodology, Y.Z.; software, H.D.; validation, Z.G., H.D., and Y.Z.; formal analysis, H.D.; investigation, Y.L.; resources, H.Z.; data curation, B.J.; writing—original draft preparation, Y.Z.; writing-review and editing, H.D., Y.Z., and S.W.; visualization, Y.Z.; supervision, Z.G.; project administration, H.Z. All authors have read and agreed to the published version of the manuscript.

Funding: This research was funded by the Development and Application Demonstration of Characteristic Land Resources in Weifang City (KC201903) and the Geochemical Investigation and Evaluation of Land Quality in Weifang City (ZFCG-2016-587).

Institutional Review Board Statement: Not applicable.

Informed Consent Statement: Not applicable.

Data Availability Statement: The data presented in this study are available on request from the corresponding author. The data are not publicly available because the project team do not allow us to publish the data of this study.

Conflicts of Interest: The authors declare no conflict of interest.

\section{References}

1. Wu, Q.; Hu, W.; Wang, H.; Liu, P.; Wang, X.; Huang, B. Spatial distribution, ecological risk and sources of heavy metals in soils from a typical economic development area, Southeastern China. Sci. Total Environ. 2021, 780, 146557. [CrossRef]

2. Lopéz, Y.P.; da Fonseca Breda, F.A.; Lima, E.S.A.; de Souza, C.d.C.B.; González, J.M.F.; do Amaral Sobrinho, N.M.B. Variability factors of heavy metals in soils and transfer to pasture plants of Mayabeque in Cuba. Environ. Monit. Assess. 2021, 193, 1-17. [CrossRef] [PubMed]

3. Ali, H.; Khan, E.; Ilahi, I. Environmental Chemistry and Ecotoxicology of Hazardous Heavy Metals: Environmental Persistence, Toxicity, and Bioaccumulation. J. Chem. 2019, 2019, 6730305. [CrossRef]

4. Jiao, W.; Chen, W.; Chang, A.C.; Page, A.L. Environmental risks of trace elements associated with long-term phosphate fertilizers applications: A review. Environ. Pollut. 2012, 168, 44-53. [CrossRef]

5. Wang, T.; Tan, C.; Cao, X.; Da, O.; Nie, J.; Wang, B.; He, Q.; Liang, Y. Effects of long-term fertilization on the accumulation and availability of heavy metals in soil. J. Agro-Environ. Sci. 2017, 36, 257-263. [CrossRef]

6. Pan, Q.U.; Yang, J.; Teng, Y.; Wang, J. Bioavailability of heavy metal in different chemical fertilizers under simulated acid rain. J. Beijing Norm. Univ. (Nat. Sci.) 2016, 52, 597-602. [CrossRef]

7. Smith, S.R. A critical review of the bioavailability and impacts of heavy metals in municipal solid waste composts compared to sewage sludge. Environ. Int. 2009, 35, 142-156. [CrossRef] [PubMed]

8. Yang, Q.; Li, Z.; Lu, X.; Duan, Q.; Huang, L.; Bi, J. A review of soil heavy metal pollution from industrial and agricultural regions in China: Pollution and risk assessment. Sci. Total Environ. 2018, 642, 690-700. [CrossRef] [PubMed]

9. Shi, J.; Liu, X.; Yu, C.; Zhu, H.; Zhao, K.; Wu, J.; Xu, J. Spatial variability and risk evaluation of soil heavy metals in taihu lake region of north Zhejiang province. Acta Pedol. Sin. 2007, 44, 824-830. [CrossRef] 
10. Han, W.; Wang, C.; Peng, M.; Wang, Q.; Yang, F.; Xu, R. Characteristics and Origins of Heavy Metals in Soil and Crops in Mountain Area of Southern Sichuan. Environ. Sci. 2021, 42, 2480-2489. [CrossRef]

11. Chen, W.; Li, Q.; Wang, Z.; Sun, Z. Spatial Distribution Characteristics and Pollution Evaluation of Heavy Metals in Arable Land Soil of China. Environ. Sci. 2020, 41, 2822-2833. [CrossRef]

12. Tedoldi, D.; Chebbo, G.; Pierlot, D.; Branchu, P.; Kovacs, Y.; Gromaire, M.C. Spatial distribution of heavy metals in the surface soil of source-control stormwater infiltration devices-Inter-site comparison. Sci. Total Environ. 2017, 579, 881-892. [CrossRef]

13. Esmaeili, A.; Moore, F.; Keshavarzi, B.; Jaafarzadeh, N.; Kermani, M. A geochemical survey of heavy metals in agricultural and background soils of the Isfahan industrial zone, Iran. Catena 2014, 121, 88-98. [CrossRef]

14. Lehmann, A.; Stahr, K. Nature and significance of anthropogenic urban soils. J. Soils Sediments 2007, 7, 247-260. [CrossRef]

15. Qu, F.; Wen, L.; Fan, C.; Liu, G.; Qin, S. Heavy metal contents in soils developed from different parent materials and their ecological risk assessment. Acta Mineral. Sin. 2020, 40, 677-684. [CrossRef]

16. Facchinelli, A.; Sacchi, E.; Mallen, L. Multivariate statistical and GIS-based approach to identify heavy metal sources in soils. Environ. Pollut. 2001, 114, 313-324. [CrossRef]

17. Amaya, F.-U.; Cristina, L.-M.; Enrique, R.; Luisa, F.-M.M. Source identification of heavy metals in pastureland by multivariate analysis in NW Spain. J. Hazard. Mater. 2009, 165, 1008-1015. [CrossRef]

18. Almasoud, F.I.; Usman, A.R.; Al-Farraj, A.S. Heavy metals in the soils of the Arabian Gulf coast affected by industrial activities: Analysis and assessment using enrichment factor and multivariate analysis. Arab. J. Geosci. 2015, 8, 1691-1703. [CrossRef]

19. Jallad, K.N. Heavy metal exposure from ingesting rice and its related potential hazardous health risks to humans. Environ. Sci. Pollut. Res. 2015, 22, 15449-15458. [CrossRef]

20. Kinuthia, K.G.; Veronica, N.; Dunstone, B.; Reuben, L.; Agnes, W.; Luna, K. Levels of heavy metals in wastewater and soil samples from open drainage channels in Nairobi, Kenya: Community health implication. Sci. Rep. 2020, 10, 8434.

21. Albanese, S.; Vivo, B.D.; Lima, A.; Cicchella, D. Geochemical background and baseline values of toxic elements in stream sediments of Campania region (Italy). J. Geochem. Explor. 2007, 93, 21-34. [CrossRef]

22. Wang, C.; Pang, X.; Wang, H.; Zeng, X.; Hu, X.; Zhen, W. High-F groundwater in Gaomi city-its genetic study. Earth Environ. 2011, 39, 355-362. [CrossRef]

23. Gao, Z.J.; Zhu, Z.H.; Liu, X.D.; Yan-Lan, X.U. The Formation and Model of High Fluoride Groundwater and In-Situ Dispelling Fluoride Assumption in Gaomi City of Shandong Province. J. Groundw. Sci. Eng. 2014, 21, 50-58. [CrossRef]

24. GB 15618-2018. Environmental Quality Standard for Soils: Risk Control Standard of Soil Pollution in Agricultural Land; Ministry of Ecology and Environment: Beijing, China, 2018.

25. GB 36600-2018. Environmental Quality Standard for Soils: Risk Control Standard of Soil Pollution in Construction Land; Ministry of Ecology and Environment: Beijing, China, 2018.

26. You, X.; Xing, T.; Yin, M.; Mei, X. Geological Characteristics and Genesis Analysis of Barite Deposit in Huashan Mine of Gaomi City. Shandong Land Resour. 2016, 32, 26-30.

27. Chen, Q.; Hao, D.; Gao, Z.; Shi, M.; Wang, M.; Feng, J.; Deng, Q.; Xia, L.; Zhang, C.; Yu, Y. The Enrichment Process of Groundwater Fluorine in Sea Water Intrusion Area of Gaomi City, China. Ground Water 2020, 58, 882-891. [CrossRef]

28. Xu, J.; Zhang, T.; Xu, H.; Zhang, Z.; Qi, X.; Ji, W. Study on Coastal Loess in the Laizhou Bay. Adv. Mar. Sci. 2019, $37,43-54$.

29. Gao, M. Particle Size Distribution Characteristics of Sediments in Holocene Linyi Formation in Dawenkou Basin in Shandong Province. Shandong Land Resour. 2018, 34, 8-13.

30. Liu, Y.; Kuang, H.; Peng, N.; Xu, H.; Liu, Y. Sedimentary facies of dinosaur trackways and bonebeds in the Cretaceous Jiaolai Basin, eastern Shandong, China, and their paleogeographical implications. Earth Sci. Front. 2011, 18, 9-24.

31. Fu, Z.; Li, Z. Characteristics and high yield and high quality cultivation techniques of leek in dajingou Town, Gaomi City. Chin. Veg. 2019, 5, 98-100.

32. Meng, X. Research on the Development of Gaomi City Brand Agriculture. Master's Thesis, Shandong Agricultural University, Tai'an, China, 2014.

33. DZ/T 0295-2016. Specification for Geochemical Evaluation of Land Quality; Ministry of Ecology and Environment: Beijing, China, 2016.

34. Xi, X.; Hou, Q. Big data based studies of the variation features of Chinese soil. Geophys. Geochem. Explor. 2021, 45, 1-14. [CrossRef]

35. DD2005-03. Technical Requirements for Analysis of Ecological Geochemical Evaluation Samples; China Geological Survey: Beijing, China, 2005.

36. Yuan, G.L.; Sun, T.H.; Han, P.; Li, J.; Lang, X.X. Source identification and ecological risk assessment of heavy metals in topsoil using environmental geochemical mapping: Typical urban renewal area in Beijing, China. J. Geochem. Explor. 2014, $136,40-47$. [CrossRef]

37. Pang, X.; Dai, J.; Chen, L.; Liu, H.; Yu, C. Soil Geochemical Background Value of 17 Cities in Shandong Province. Shandong Land Resour. 2019, 35, 46-56.

38. Pang, X.; Dai, J.; Hu, X.; Song, Z. Background Values of Soil Geochemistry in Shandong Province. Shandong Land Resour. 2018, 34, 39-43.

39. Chiroma, T.M.; Ebewele, R.O.; Hymore, F.K. Comparative assessment of heavy metal levels in soil, vegetables and urban grey water used for irrigation in Yola and Kano. Int. Refereed J. Eng. Sci. 2014, 3, 1-9.

40. Xu, Y.L.; Feng, G.L.; Jiang, X.; Liu, N.; Yang, Y.L. Distribution characteristics of heavy metals in soil and its influence on greening plants in a main road of Lanzhou City, Northwest China. J. Appl. Ecol. 2020, 31, 1341-1348. 
41. Yang, Y.; Liu, A.; Chao, L.; Shan, Y.; Wu, N.; Chen, H.; Wang, M. Spatial Distribution of Soil Heavy Metals of Opencut Coal Mining in Inner Mongolia Xilingol Typical Steppe. Ecol. Environ. Sci. 2016, 25, 885-892. [CrossRef]

42. Han, Y.; Du, P.; Cao, J.; Posmentier, E.S. Multivariate analysis of heavy metal contamination in urban dusts of Xi'an, Central China. Sci. Total Environ. 2005, 355, 176-186. [CrossRef]

43. Lu, H.; Xiao, G.; Liu, Q.; Peng, X. Advances in soil Cd pollution and solution measures. J. South. Agric. 2014, 45, $1986-1993$.

44. Yan, X.; Zheng, H.; Zhao, X.; Yu, Y.; Zhong, J. Source identification and health risk assessment of soil heavy metal in the estuary of Northern Liaodong Bay, China. Acta Sci. Circumstantiae 2020, 40, 3028-3039. [CrossRef]

45. Huang, Z.; Guan, D.; Wang, G. Heavy metal contents of mangrove surface soils affected by the social and economic development in Hainan Island. Mar. Environ. Sci. 2020, 39, 831-837. [CrossRef]

46. Zhang, H.; Yin, A.; Yang, X.; Fan, M.; Shao, S.; Wu, J.; Wu, P.; Zhang, M.; Gao, C. Use of machine-learning and receptor models for prediction and source apportionment of heavy metals in coastal reclaimed soils. Ecol. Indic. 2021, 122, 107233. [CrossRef]

47. Lars, H. An ecological risk index for aquatic pollution control.a sedimentological approach. Pergamon 1980, 14, 975-1001. [CrossRef]

48. Xu, Z.; Ni, S.; Tuo, X.; Zhang, C. Calculation of Heavy Metals'Toxicity Coefficient in the Evaluation of Potential Ecological Risk Index. Environ. Sci. Technol. 2008, 31, 112-115. [CrossRef]

49. Kumar, P.K.; Sumanta, N.; Manash, G.; Kumar, R.A.; Rajnarayan, S. Sources evaluation, ecological and health risk assessment of potential toxic metals (PTMs) in surface soils of an industrial area, India. Environ. Geochem. Health 2020, 42, 1-22. 